\title{
Overview of extravasation management and possibilities for risk reduction based on literature data
}

\author{
Béla Pikó ${ }^{1}$, I bolya Laczó ${ }^{1}$, Klára Szatmári ${ }^{1}$, Ali Bassam ${ }^{1}$, Zsolt Szabó ${ }^{1}$, Henriette Ócsai ${ }^{2}$, János \\ Csotye $^{3}$
}

1. Oncology Center, Pándy Kálmán County Hospital, Gyula, Hungary. 2. Outpatient Clinic for Dermatooncology, Pándy Kálmán County Hospital, Gyula, Hungary. 3. Department of Traumatology, Pándy Kálmán County Hospital, Gyula, Hungary

Correspondence: Ibolya Laczó. Address: Oncology Center, Pándy Kálmán County Hospital, Gyula, Hungary. Email: laczoibolya@freemail.hu.

Received: September 14, 2012

Accepted: January 9, 2012 Online Published: March 6, 2013

DOI : $10.5430 /$ jnep.v3n9p93

URL: http://dx.doi.org/10.5430/jnep.v3n9p93

\section{Abstract}

Background: The escape of cytostatic drugs from the blood vessels (paravasation, extravasation) during peripheral intravenous administration is a relatively frequent complication; in the United States of America it is reported in seven percent of cases with different severity and consequences. Although methods to completely avoid this complication are still unavailable, we are able to decrease its risk by identifying the patient and procedure-related factors.

Methods: In this article the risk factors of extravasation, its prevention possibilities and in case of its development the available treatment choices will be reviewed based on the relevant literature data.

Conclusion: The patient - if he/she was adequately informed - is a good indicator of extravasation therefore in case of patient's cooperation was not reliable due to any reason a closer nursing surveillance is required. The severity of tissue injury depends mainly on the chemical structure of the substance escaping from the blood vessels into the surrounding tissues (vesicant, irritant or non-vesicant) which may be modified by other factors as well. There are no high-level evidences available for the management of this complication, immediate discontinuation of the infusion and making an attempt to draw back the escaped drug through the cannula, elevation and immobilization of the affected extremity are required. Literature is contradictory about cooling or warming of the affected area and similarly there are still open questions regarding the value of using antidotes (dexrazoxane, dimethylsulfoxide, thiosulfate and hyaluronidase). If extravasation occurs early referral to dermatologist and surgeon is inevitable for definitive diagnosis and choosing the optimal management.

\section{Key words}

Extravasation, Escape of cytostatic drugs, Prevention, Treatment

\section{Introduction}

\subsection{Definition of extravasation and its causes}

Cytostatic agents are mainly administered intravenously, as a form of intravenous bolus injection, high or normal flow rate or permanent infusion. Escaping from the blood vessels they cause usually (but not in every case) more or less serious 
tissue damages (pain, inflammation, tissue necrosis). The name of the phenomena is not uniform, both the term of paravasation ("getting beside the vessel”) and extravasations ("escaping out of the vessels”) are applied.

The cause of it is the mechanical impairment of the blood vessel wall (typically the injury caused by the needle, mostly after repeated venous puncture or the irritative effect of peripheral venous cannula). It can be induced by the weakness of the damaged, injured blood vessels occurring after repeated venous puncture or frequent drug administration during repeated treatments or related to contrast enhanced imaging methods or supportive therapy, and the effect of higher drug concentration due to infusion related higher pressure and slower flow in the punctured small veins ${ }^{[1-5]}$.

\subsection{Incidence of extravasation and the possibility of risk increase}

\subsubsection{I ncidence of extravasation}

Extravasation incidence data vary, in the United States of America it is reported as $0.1-7 \%{ }^{[2,5-17]}$. There are no exact Hungarian data available about the incidence of extravasation. Mrs. Zatkó reported complications with "no serious consequences" (but not precisely determined) in case of $0.1 \%$, but the incidence of all events is not detailed ${ }^{[2]}$. The risk of extravasation can be reduced significantly by using centrally vein accessed ports and subcutaneously implanted „reservoirs” (subcutaneously implanted ports), but using this method cannot even guarantee to avoid this complication and in addition to the effects of cytostatic agents escaping into the tissues centrally, also unusual complications may develop ${ }^{[5,10,11,18-27]}$.

\subsubsection{Causes of increased risk}

During the longer and longer treatment periods the number of the diagnostic blood sample drawing and contrast enhanced control imaging methods is ever increasing. There is also a change in the palliative and supportive approach both during the active treatment and terminal phase. These changes are unavoidable accompanied with repeated venous punctures, more frequent - often permanent - administration of infusions and consequently, increased impairment of the veins ${ }^{\text {[28-31] }}$.

In practice, besides these difficulties (and in spite of them) a case is considered typical when anticancer therapy is administered through a peripheral vein and as complication no extravasation occurs.

\subsubsection{Methods of risk-reduction}

The aim of our publication is to provide an overview about the risk factors of extravasation, the possibilities of risk reduction and the alleviation of its complications based on literature data and also considering the international guidelines. Although the legal systems and the judicial practice are different in every country, keeping the generally accepted professional rules, working according to the specified algorithms and its proper documentation can provide protection for the nurses and doctors everywhere.

\section{Objectives}

In what follows, we will make an examination how the risk of extravasation can be reduced (although complete protection cannot be provided) and in case of its development what kind of management is required.

\subsection{Design}

Literature data collected in the last few years were reviewed in connection with a damage claim.

\subsection{Procedures}

Relevant literature data were reviewed systematically regarding each step of chemotherapy procedures. 


\subsection{Data analysis}

By reviewing these literature data we identified several factors the presence or absence of which may significantly contribute to the development of extravasation and are therefore essential for the optimal management of a patient receiving chemotherapy as in full aware of these facts the incidence of extravasation may be reduced.

\section{Results}

\subsection{Risk factors}

\section{Non-informed patient}

Decreasing the risk of extravasation begins with the adequate patient information process and continues with the adequate administration of the cytostatic mixture infusion (into suitable vein, according to the prescriptions). Detailed legal consequences of the informed consent are not considered in this publication. We'd like to notice that the patient must be informed that anticancer drugs used for the treatment can induce -even more serious- side effects if escaping into the tissues and the fact of informing the patient and his/her acceptance must be well documented. We find useful and therefore suggest making it absolutely clear during the informing process that the patient co-operation is also essential for the safe treatment.

\section{Patient related risk factors}

Patient related risk factors are shown in Table $1^{[3,17,32,33]}$. The presence of these factors does not mean of course that these patients cannot be treated, but special attention is needed during the treatment of these patients regarding selection and puncture of the adequate vein and closer observation is required as usual during administration of infusion and also after it.

Table 1. Patient-related risk factors ${ }^{[2,3,17,33]}$

\begin{tabular}{|l|}
\hline $\begin{array}{l}\text { Veins difficult to puncture (thin or fragile blood vessels, generalized vascular diseases, multiple previous punctures and vasospasm } \\
\text { as the consequence of these, obesity) }\end{array}$ \\
\hline Prolonged bleeding and clotting time due to decreased platelet count or other cause \\
\hline $\begin{array}{l}\text { Decreased blood flow, higher blood pressure, congestion (e.g. disturbance in lymphatic system or superior vena cava syndrome and } \\
\text { other blood vessels compression) }\end{array}$ \\
\hline Tumorous infiltration of the area \\
\hline Other skin infiltrating diseases \\
\hline Former vessel obstruction due to any reason \\
\hline Age (smaller veins in children, sclerotic and fragile veins in elderly patients) \\
\hline Sensation disturbance, loss of sensation on the affected area (e.g. neuropathy) \\
\hline Neurologic disorders with involuntary movements (e.g. tremor) \\
\hline Insufficient ability to cooperate (mental disorders, patient under the effect of a sedative or a tranquilizer) \\
\hline $\begin{array}{l}\text { Communication problems (e.g. inability to speak or speech scarcely audible, difficult to understand in patient with head and neck } \\
\text { cancer, difficulties with operating nurse call system in case of some neurologic disorders, medical sedation) }\end{array}$ \\
\hline "Recall phenomenon” after previous radiotherapy, administration of doxorubicin and paclitaxel \\
\hline
\end{tabular}

\section{Treatment related risk factors}

In the practice of patient care the method how the infusion is accessed into the vein and the treatment is administered are also important. Relating risk factors are summarized in Table $2^{[2,3,15,29,33-36]}$. Although knowing all of these factors it can also occur that we are constrained to give the treatment using other than the suggested veins and the recommended way. The most frequent cause of this are the previous impairment of "optimal” puncture sites (see Figure 1), the "worn-out" veins and insufficient availability of the venous access port meaning the solution of the problem. If the infusion pump was incorrectly set and the vein was inadequately selected the solution is administered with more pressure than gravity causing 
also physical damage to the blood vessels ${ }^{[3,29,35]}$. Nursing and medical surveillance of the patient and emergency care in case of extravasation depend significantly on the departmental circumstances (staff number, proportion of skilled staff, out-of-hours doctor service) and patient's co-operation. Fixed rules (frequency of nurse and doctor visits, method and extent of it) cannot be determined; we can say with little cynicism that the adequate (expectable) surveillance is that during which no complication occurs.

Table 2. Treatment related risk factors $[2,3,15,16,33-36,44,45]$

Inadequate vein selection (forearm veins are considered ideal for vein punctures) (see Figure 1). Puncture of small, fragile veins adjacent to tendons or nerves - at the back of the hands and feet - should be avoided; after breast surgery the arm on the operated side is not to be chosen due to the impaired venous blood flow. Take care of adequate fixation of the cannula (infusion should not be inserted in the elbow pit because of the risk of its displacement). Treatment administered through a former impaired vein (e.g. discolored veins due to permanent 5-fluorouracil administration or chemical inflammation of the veins) is associated with higher risk.

Treatment administered by long-term venous cannulation (mechanical or former chemical irritation of the blood wall, reduced resistance due to inflammation invisible to the naked eye or a thrombotic injury)

Repeated, failed punctures of the vein at the same site (blood wall injuries towards the blood flow from the actual site of the infusion mean risk for extravasation).

Administration of infusion through a metal needle (the rigid metal part of the winged needle suitable for diagnostic puncture of the small veins and for "rapid" drug administration is accompanied by increased mechanical risks, particularly in case of prolonged or permanent infusion and after its removal the risk of late-onset bleeding is higher.)

Starting the infusion therapy using cytostatic mixture infusion (the position of the cannula and the condition of the vein are necessary to be checked in every case administering at least $10 \mathrm{ml}$ of saline infusion or possibly $5 \%$ sugar solution, while inspecting the area and asking the patient about any possible complaints). Drawing back blood through the needle as necessary may also help to decide whether the cannula is properly placed in the vein.

Insufficient fixation of the cannula and/or the arm and therefore the risk of displacement of the cannula (thus selecting an inadequate vein is not recommended as the stabilization can be difficult)

Too fast (unsuitable to the vein diameter) infusion flow rate (especially infusion pump can be associated with higher risk).

Delivering different agents in the same mixture infusion (physical, chemical incompatibility, unpredictable effect on the inner membrane of the blood vessel and if extravasation occurs, the selection of proper treatment is difficult).

Administering several cytostatic agents not in the right order (in the best condition of blood vessels first the administration of vesicant drugs is recommended)

Inadequate supervision of the patient

Disregarding the effects of other drugs (e.g. vasodilatators, anticoagulants, steroids, diuretics, pain killers)

Delayed adequate treatment in case of extravasation (insufficient skill, problems with work organization, lack of extravasation kit)

Figure 1. Superficial veins of the upper limb are suitable for infusion insertion. (Due to the developmental anomaly of the blood vessels the figure is very simplified, idealized and only informative)

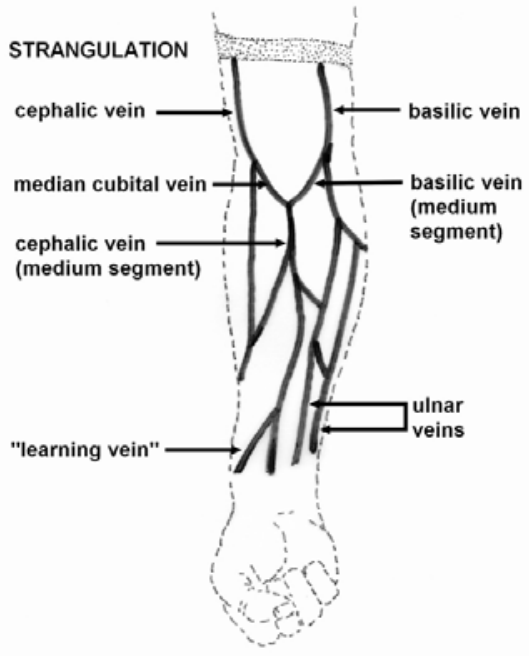




\subsection{Factors influencing the severity of complications}

\section{General causes}

Nevertheless if extravasation occurs, the extent of injury depends mainly not on the quantity of the cytostatic agents escaping from the blood vessels, but on the chemical structure (and mechanism of action respectively), chemical reaction, osmolarity, concentration and the direct effects on blood vessels (e.g .vasoconstriction or vasodilatation) of the cytostatic drugs, furthermore, injury is also influenced by the way of administration, duration of extravasation, site of extravasation, previous tissue status and the treatment applied after detecting the complication as well ${ }^{[1-3,11,16,20,32,37]}$.

\section{Groups of anticancer agents}

In the relevant literature anticancer drugs are divided into three main groups according to their effect on tissue: vesicant drugs, causing very likely tissue necrosis, irritant drugs with milder complications and non-vesicant drugs with minimal consequences (possibly nothing at all). The new biological targeted drugs differing from the traditional cytostatic agents both in their effects and side effects can be classified according to this method as well. In practice it can cause considerable problem that the classification of the drugs -and therefore the correct treatment of extravasation - differ among authors (see Table 3) ${ }^{[1-3,5,8,9,11,20,32,38]}$.

Table 3. Classification of the most frequent anticancer agents according to the consequences following extravasation $^{[2,5,8,9,20,65-67]}$

\begin{tabular}{|c|c|c|}
\hline Vesicant drugs & Irritant drugs & Non-vesicant drugs \\
\hline Actinomycin D & Bleomycin $* * / * * *$ & Asparaginase \\
\hline Amsacrine & Carboplatin ** & Bevacizumab \\
\hline Cisplatin * & Carmustine $* *$ & Cetuximab \\
\hline Dacarbazine * & Cyclophosphamide ** & Cytarabine \\
\hline Dactinomycin & Fludarabin & Estramustin \\
\hline Daunorubicin & Fotesmustine & Interferon \\
\hline Docetaxel * & Gemcitabine $* * *$ & Interleukin \\
\hline Doxorubicin & Ifosfamide & Methotrexate \\
\hline Epirubicine & Irinotecan $* * *$ & Panitumumab \\
\hline Esorubicin & Melphalan** & Rituximab \\
\hline Etoposide * & Pentostatin & Trastuzumab \\
\hline Fluorouracil */*** & Plicamycin & \\
\hline Idarubicin & Raltitrexed & \\
\hline Liposomal doxorubicin $* * *$ & Streptozocin & \\
\hline Menogaril & Teniposide & \\
\hline Mitomycin-C & Topotecan & \\
\hline \multicolumn{3}{|l|}{ Mitoxantrone } \\
\hline \multicolumn{3}{|l|}{ Oxaliplatin * } \\
\hline \multicolumn{3}{|l|}{ Paclitaxel * } \\
\hline \multicolumn{3}{|l|}{ Vinblastine } \\
\hline \multicolumn{3}{|l|}{ Vincristine } \\
\hline \multicolumn{3}{|l|}{ Vindesine } \\
\hline Vinorelbine & & \\
\hline
\end{tabular}

* belongs to irritant drugs according to other classification; **belongs to vesicant drugs according to other classification; ***belongs to non-vesicant drugs according to other classification 


\subsection{Symptoms}

\section{Symptoms and complaints}

Symptoms occur in majority of cases promptly and the most reliable indicator of mixture infusion escaping into the tissue is the patient who - if he/she was adequately informed and had reliable co-operative ability and skill -indicates it immediately (pain, tightening, burning and any other unusual local sensation) ${ }^{[5,16,18,29,34-36,39,40-42]}$.

\section{Physical examination}

Physical examination of the affected area can reveal swelling (it depends on the nutritional status of the patient and whether the escape aims at the skin or the deeper layers), redness or a faint area due to vasoconstriction, maybe blistering can also be seen or limb movements become restricted due the pain ${ }^{[2,5,8,9,11,16,17,29,33-35,39,42-45]}$. Usually no blood can be drawn back through the cannula (this does not absolutely mean that it has been displaced, because it can occur that the vein valves allow only one-way flow). It can occur that the symptom accompanying the patient's complaint develops only later, in this case it is advisable to consider the complaints primary during the decision making process ${ }^{[2,9]}$. As a basic rule it can be advised every suspected case should be treated as paravasation as long as its opposite has been proved ${ }^{[5,20,29,33,44,45]}$.

\subsection{Therapeutic possibilities in the management of extravasation}

\section{Nurse's responsibilities}

Unfortunately besides the drug classification there is also conflicting literature data on recommendations regarding the management of extravasation, therefore the followings should be considered not a "strict rule" but the presentation of the possibilities. We have to accept that no high level evidences are available because the necessary prospective randomized clinical studies on the treatment of extravasation cannot be organized to determine the level of evidences. The management of extravasation is performed on the basis of demonstrating successful practical guidelines of some institutions and probably according to historical data ${ }^{[32,33,46,47]}$.

In practice extravasation is usually detected by a nurse who also begins its management therefore she should be familiar with the symptoms and the first treatment steps (which are the most important) because waiting for a doctor's instructions causes wasting of valuable time. Primary step is immediate stopping the administration of drugs by disconnecting the infusion. Cannula should not be removed yet, but try to draw back as much drugs as possible ${ }^{[2,5,8,16,17,20,29,32-36,43-45]}$. Opinions strongly differ on whether the escaped drugs should be "pressed" from the tissues through the injection site, because vasocompression can occur as an effect of pressure and more tissue damage can be induced ${ }^{[29,33]}$, but according to some authors this method is reasonable ${ }^{[6]}$. Heat-treating (controlled cooling or heating) should be started as early as possible, related guidelines of ESMO (European Society of Medical Oncology) are presented in Table 4. (However, these also include doubtful items) ${ }^{[2,29,34,35,43,48]}$. Choosing whether cooling or heating it is important to apply dry cooling or heating - to avoid the skin wetting - and heat treating should not only be constant but regularly interrupted in order to preserve the normal circulation of the skin ${ }^{[2,5,7,15,16,29,34,35,40,43-45,48,49]}$.

Elevating and putting the affected limb in resting position are recommended in every case, by this way hydrostatic capillary pressure can be reduced and some of the escaped drugs get back into the bloodstream and the patient's pain can be alleviated ${ }^{[3,5,15,33,45]}$.

As the tissue damage caused by cytostatic drugs escaping from the vessels cannot be avoided, and also considering its frequency, there is a need for defining the uniform content of an "extravasation kit" containing the required drugs and equipments and including it to quality-control requirements ${ }^{[33,35,46,49]}$. 
Table 4. Administration of heat effect after extravasation of cytostatic drugs according to the ESMO guideline ${ }^{[52]}$

\begin{tabular}{ll}
\hline Cytostatic drugs needing cooling & Cytostatic drugs needing heating \\
\hline Actinomycin D & Etoposide \\
Adriblastin & Vinblastine \\
Amsacrine & Vincristine \\
Carboplatin & Vindesine \\
Carmustine & Vinorelbine \\
Cispatin (ambiguous) & \\
Dacarbazine (possibly with sun protection) & \\
Daunorubicin & \\
Docetaxel & \\
Epirubicin & \\
Fludarabine & \\
Fluorouracil & \\
Gemcitabine & \\
Idarubicin & \\
Irinotecan & \\
Liposomal doxorubicin & \\
Mechlorethamine (ambiguous ) & \\
Mitomycin C & \\
Novantrone & \\
Oxaliplatin & \\
Paclitaxel * & \\
Streptozotocin & \\
Topotecan & *according to the ESMo guideline the possibility of 24 hours heating followed by cooling arises as well. Literature data are available for cooling, [2], [34], [43] avoiding cooling, [29] or heating [35] as \\
well. & \\
\end{tabular}

\section{Documentation}

Documentation of the extravasation is an important task but this process should not have effect on initiating the treatment in due time. Taking photographs of the affected area is recommended. There is certainly a cell phone in every shift which is suitable for taking pictures of sufficient quality; it is practical to mark the affected area - e. g. using a pen - and it is worth taking more pictures from different distances, directions and using proper exposure. Considering the possibilities of digital image processing not only the printed image but also the original image file should be preserved ${ }^{[47-50]}$.

Taking pictures of the affected area does not exempt us from exact nursing and medical documentation (see Table $5)^{[2,3,5,20,29,35,36,43-45]}$. The nurse's duties include the immediate information of the doctor about the event.

\section{Doctor's responsibilities}

Administration of local injection (mixture of normal saline, steroid and local anesthetic) as a non-specific treatment during medical care, in the hope of diluting the drug, reducing pain and inflammation, is not absolutely recommended by available literature. Although steroid drugs do not get into the area in such a concentration that could cause local damage but its application is unnecessary because no real inflammation exists and may promote the development of infections by inhibiting the immune processes ${ }^{[33]}$. At the same time, other authors recommend this method and report favourable results ${ }^{[3,5,11,40,57]}$. Systematic steroid administration is recommended ${ }^{[51]}$. In pain management systemic administration of proper analgesics is favoured instead of local anesthetics. 
Table 5. The most important data to be recorded in case of extravasation (overlapping or complementary data in nursing and medical documentations are not separated for the sake of simplicity) ${ }^{[2,3,5,29,33,44,45]}$

\begin{tabular}{|l|}
\hline $\begin{array}{l}\text { Patient identification data (if the event is recorded in the medical documentation completed continuously there is no need for this } \\
\text { step) }\end{array}$ \\
\hline Exact time and date of the extravasation has been detected (nurse and medical as well) \\
\hline The possibly precise specification of the body area (maybe drawing of it) where the extravasation has occurred \\
\hline Method of administration (peripheral cannula, central cannula, port, gravitational infusion set, infusion pump) \\
\hline $\begin{array}{l}\text { Numbers and results of attempt of former puncture (unsuccessful punctures, infusion stopped due to vein injury during puncture, } \\
\text { clotted, replaced cannula, etc..) }\end{array}$ \\
\hline $\begin{array}{l}\text { Denomination of the extravasated drug (amount of active agent in the infusion from which the concentration can be calculated), if it } \\
\text { is uncertain from which consecutively administered mixture infusion was extravasated all of the agents should be recorded }\end{array}$ \\
\hline If it is possible the estimation of the drug extravasated into the tissues \\
\hline Complaints of the patients \\
\hline Alteration detected by nurse/doctor \\
\hline $\begin{array}{l}\text { Possibly picture should be taken (camera, phone), finding of the pictures (besides preserving the picture-file it is practical as well to } \\
\text { place the printed picture or pictures in the medical documentation later) }\end{array}$ \\
\hline $\begin{array}{l}\text { Description of nursing and medical supply (stopping the infusion, drawing back blood, cooling or heating, elevation and taking in } \\
\text { rest the affected limb, giving "antidotes”, administering steroids, pain management) }\end{array}$ \\
\hline The fact that the patient was informed and the short content of it \\
\hline Possible medical consultations (surgery, dermatology) \\
\hline Plans for further supply \\
\hline Signature of nurse and doctor
\end{tabular}

\subsection{Contradictions about the use of antidotes}

\section{Dexrazoxane (Savane ${ }^{\circledR}$ )}

The use of "antidotes" during paravasation is conflicting as well. The only real antidote which may be used in anthracycline extravasation is the well-known dexrazoxan (Savene ${ }^{\circledR}$ ) which is administered for preventing cardiotoxicity ${ }^{[56]}$. According to the summary of product characteristic it is unknown which from the two reported mechanism of action (forming chelates or blocking the effect of topoisomerase II) contributes to and to what extent to the tissue protection. The first Savane ${ }^{\circledR}$ dose should be administered within 6 hours following extravasation in a dose of $1000 \mathrm{mg} / \mathrm{m}^{2}$ at the beginning and on the following day then on third day the half dose of it should be given (total dose of $2000 \mathrm{mg}$ should not be exceeded even in case of higher body surface area). Side effects of the drug cannot be correctly determined as it was administered after cytostatic infusions in every clinical study and the consequences of the cytostatic drugs defined mainly the symptoms. The product is recommended in several articles ${ }^{[2,3,7-9,11,16,18,20,35,40,41,44,45]}$.

\section{Dimethyl sulfoxide (DMSO)}

The mechanism of action of DMSO (dimethyl sulfoxide) is complex: reduction of local inflammation, pain relief, vasodilatation, scavenging free radicals and damaging collagen fibers contribute to its mechanism of action and help the escaped cytostatic drugs to be absorbed. Recommendation for use is not uniform: in Europe a concentration of 90\%-99 \%, in USA that of 50\%-70 \% is recommended. Its administration should be started within 10-25 minutes: in every 8 hours it should be painted on the skin and wait for drying, undiluted solution should be applied for at least 7 days and the diluted solution for 10-14 days. Combination with cooling the affected area in case of cisplatin, anthracyclines, mitoxantron, mitomycin, amsacrine or taxanes extravasation is also possible. Some authors find the administration of DMSO contraindicated in extravasation of liposomal doxorubicin as it may help the cytotoxic drug to release from the liposome and thus increase its local toxicity ${ }^{[33]}$; other authors recommend its application in this situation as well ${ }^{[35]}$. DMSO solution should not be rubbed into the skin or the tissues and should not be applied in occlusive bandage. Side effects of DMSO are mild: redness, slight burning sensation, possibly hives or garlic-breath odor. Its administration in combination with dexrazoxan is not suggested ${ }^{[2,3,5,7,16,18,29,33,37,40,41,43,57]}$. 


\section{Hyaluronidase}

Hyaluronidase enzyme is also included in guidelines as a material which breaks down the connective tissue bands; administered cutaneously or subcutaneously it helps the escaped drugs to expand and thus the local concentration and the side effects decrease. Its application is primarily recommended with combination of dry heat if vincristine, vinblastine, vindesine, vinorelbine extravasation occurs, but there is recommendation for extravasation of paclitaxel, in this case without local heating; however, there is no consensus regarding its application, and safety ${ }^{[3,5,7-9,17,20,29,35-37,39,40,43]}$.

\section{Sodium thiosulfate solution}

Thiosulfate solution (sodium thiosulfate) reacts with free radicals and inactivates the extravasated cytostatic drugs by alkylation. In case of mitomycin, cisplatin, anthracyclines, vinblastine, nitrogen mustard or extramustine extravasation an infiltration with 1/3-1/6 molar solution of sodium thiosulfate is a therapeutic possibility, but some authors are not convinced about its efficacy and safety ${ }^{[2,3,5,8,11,16,20,35,37,43]}$.

\section{Other methods}

Regarding the extravasation of non-vesicant drugs the recommendations are confined to general treatment instructions: stopping the infusion immediately, drawing back the extravasated drug through the needle, elevating and putting the affected limb in resting position, proper documentation and informing the patient about the incident and the need for follow-up visits. Cooling of the affected area (also avoiding skin wetting) and in case of complaints pain relief is recommended ${ }^{[33,45]}$ In our practice ointments and creams containing non-fluorized steroid are applied on the affected area, and nowadays the oral administration of diosmin + hesperidin (in Hungary: Detralex ${ }^{\circledR}$ ) arises as well, however, in this indication in Hungary - according to the recommendations for use - its use requires special permission and is regarded off-label treatment ${ }^{[58]}$.

\subsection{Consultations}

If extravasation is detected consultations are required. A dermatologist (ideally oncodermatologist) and a surgeon (often plastic surgeon) can provide the most assistance during management of extravasation.

\section{Dermatologist}

Although extravasation in most cases can be easily detected by the clinical oncologist (even the nurse as well) based on medical history and the clinical picture, those possibilities should be considered as well when the opinion of the dermatologist can be decisive. Complications - as it was mentioned before - have not always immediate symptoms ${ }^{\text {[2, 9, 33] }}$ and skin lesions change as time passes ${ }^{[5,29,43,55]}$. During the process of differential diagnosis extravasation may have to be distinguished from local hypersensitivity reactions, thrombophlebitis, allergic symptoms, flare or recall phenomenon ${ }^{\text {[33] }}$. Cutaneous complications of certain groups of anticancer drugs (e.g. EGFR and proteasome inhibitors, multikinase inhibitors) are well known but in literature other drugs and other presentation forms are reported as well. Signs of extravasation combined with these symptoms may not be absolutely typical, and the help of a dermatologist experienced in cytostatic drugs is essential for setting up the diagnosis as well as for making therapeutic decision on the treatment of the affected area ${ }^{[8,34,39]}$.

\section{Surgeon}

After detection of extravasation referral to a surgeon is recommended as early as possible. Relating literature contains recommendations for the early and late surgical intervention as well. During the early surgical intervention the foreign substances are eliminated by subcutaneous washing out procedure ("flush out"). Gault ${ }^{[59]}$ reported first the method during which after injecting hialuronidase an amount of $500 \mathrm{ml}$ saline solution was used to wash out the area, later Khan and Holmes ${ }^{[60]}$ modified this procedure by addition of local anesthetics. In the beginning the material diluting the tissue damaging substances was administered by incision, later the saline solution was injected by proper equipments (Veress-needle, plastic cannulae). This intervention should be performed as soon as possible but not later than 24 hours, 


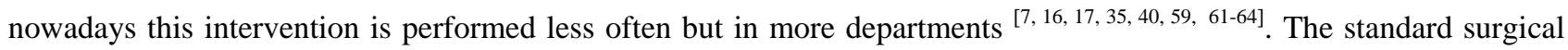
intervention involves removal of the obvious necrotic tissue and plastic surgery to cover the affected area (wait and see policy) $^{[2,3,7,9,16,17,34,35,38,40,42,54]}$ ) (see Figure 2). Waiting for the definitive status can cause huge discomfort for the patient, and it may require complicated and repeated plastic surgical interventions, long-term follow-up care, physiotherapy and the assistance of physiotherapist and if extravasation occurs especially next to tendons and joints, it results in loss of function. To avoid these complications it is worth to consider the possibility of early surgical intervention by early surgical consultation.

Figure 2. Condition after 2 years the cytostatic drug, anthracycline administering into the vein of the back of the hand was extravasated. Despite after repeated necrectomy, tissue transplantations, careful physiotherapy and excellent cooperation of the patient neither the esthetical nor the functional result is excellent. (swollen fingers, circle formation can be carried out with difficulties, reduced hand force compared to the other hand, and the affected hand can be used with limitations.)

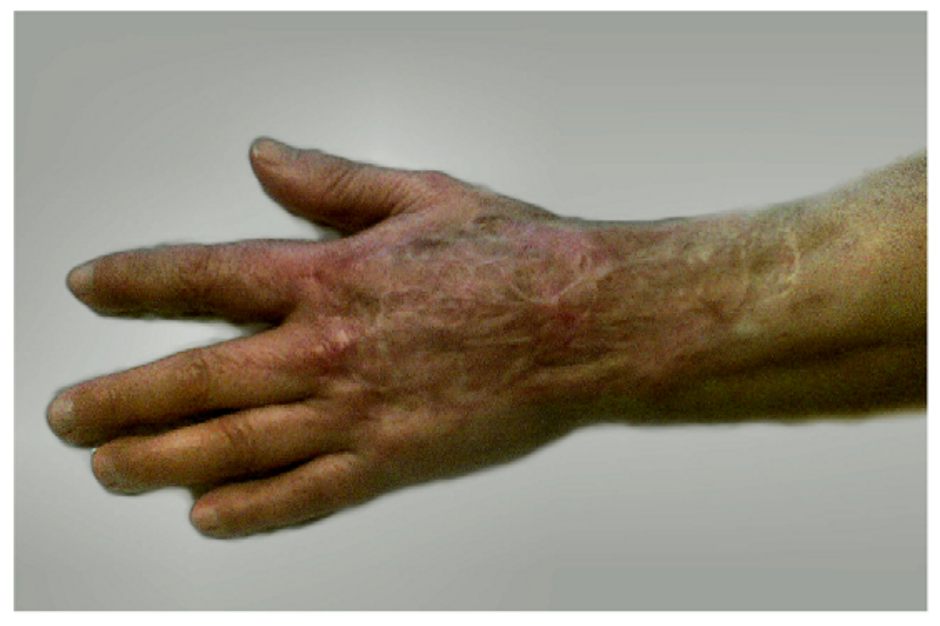

\section{Conclusion}

As we cannot provide a method by the use of which the escape of cytostatic agent from the blood vessels (extravasation, paravasation) could be completely avoided, it is important to minimize the risk. In addition of using adequate veins (or venous ports) professionally and closer surveillance of high-risk patients, the reduction of the complications caused by extravasation is essential as well. In every department where anticancer chemotherapy is administered regularly, establishing an adequate protocol and training the medical staff about the detection of the event, the immediately required tasks, both professionally and legally acceptable documentation, information of the doctor and the consultations initiated by the doctor are required. Immediate availability of the check-list of interventions for medical staff is inevitable as well as the assembling of a regularly revised "extravasation kit" containing items according to the department protocol. The up-to-date theoretical knowledge and the knowledge of interventions in case of extravasation as a routine together provide the adequate safety for patients to avoid the development of extravasation and to decrease the severe consequences.

\section{References}

[1] Goolsby TV, Lombardo FA. Extravasation of chemotherapeutic agents: prevention and treatment. Semin Oncol. 2006; 33: 139-143. PMid:16473651 http://dx.doi.org/10.1053/j.seminoncol.2005.11.007

[2] Zatkóné Puskás G. The importance of extravasation in oncological care. (English abstract) Hungarian Oncol. 2008 ; 52: 75-80.

[3] Doellman D, Hadaway L, Bowe-Geddes LA et al. Infiltration and Extravasation, Update on Prevention and Management. J Infus Nursing. 2009; 32: 203-211. PMid:19605999 http://dx.doi.org/10.1097/NAN.0b013e3181aac042

[4] Rudolph R, Larson DL. Etiology and treatment of chemotherapeutic agent extravasation injuries: a review. J Clin Oncol. 1987; 5(7): 1116-1126. PMid:3298560

[5] Ener RA, Meglathery SB, Styler M. Extravasation of systemic hemato-oncological therapies. Ann Oncol. 2004 ; 15 : 858-862. PMid:15151940 http://dx.doi.org/10.1093/annonc/mdh214 
[6] Kassner E. Evaluation and treatment of chemotherapy extravasation injuries. J Pediatr Oncol Nurs. 2000; 17: 135-148. PMid:10944862 http://dx.doi.org/10.1053/jpon.2000.8063

[7] Langer, SW, Sehested M, Jensen PB. Treatment of Anthracycline Extravasation with Dexrazoxane. Clin Cancer Res. 2000; 6: 3680-3686. PMid:10999761

[8] Sanborn RE, Sauer DA. Cutaneous Reactions to Chemotherapy: Commonly Seen, Less Described, Little Understood. Dermatol Clin. 2008; 26: 103-119. PMid:18023774 http://dx.doi.org/10.1016/j.det.2007.08.006

[9] Schrijvers DL. Extravasation: a dreaded complication of chemotherapy. Ann Oncol. 2003; 14 (Supplement 3): iii26-iii30. PMid:12821535 http://dx.doi.org/10.1093/annonc/mdg744

[10] Lemmers NWM, Gels ME, Sleijfer DT, et al. Complications of Venous Access Ports in 132 Patients with Disseminated Testicular Cancer Treated with Polychemotherapy. J Clin Oncol. 1996; 14: 2916-2922. PMid:8918488

[11] Watanabe H, Ikesue H, Yoshida M, et al. Protection Against the Extravasation of Anticancer Drugs by Standardization of the Management System. Hospital Pharmacy. 2008; 43: 571-576. http://dx.doi.org/10.1310/hpj4307-571

[12] Adami NP, de Gutiérrez MG, da Fonseca SM, et al. Risk management of extravasation of cytostatic drugs at the adult chemotherapy outpatient clinic of a university hospital. J Clin Nurs. 2005; 14: 876-882. PMid:16000102 http://dx.doi.org/10.1111/j.1365-2702.2005.01124.x

[13] Donehower RC, Rowinsky EK, Grochow LB, et al. Phase I trial of Taxol in patients with advanced cancer. Cancer Treat Rep. 1987; 71: 1171-1177. PMid:2891441

[14] Liau DW. Injuries and liability related to peripheral catheters: a Closed Claims analysis. Newsl Am Soc Anesthesiol [Internet]. 2006; 70(6). Available from: http://www.asahq.org/Newsletters/2006/06-06/liau06_06.html

[15] McLauchlan R. Extravasation Update, HOPA (Hematology Oncology Pharmacy Association, Presentation [Internet]. 2008. Available from: https://www.hoparx.org/documents/5.\%20HOPA\%20ISOPP\%202008,\%20McLauchlan\%20Extravasation\%20Update.\%20Work shop\%205.pdf

[16] Froiland K. Extravasation Injuries - Implications for WOC Nursing. J Wound Ostomy Continence Nurs. 2007 ; $34: 299-302$. PMid:17505251 http://dx.doi.org/10.1097/01.WON.0000270826.22189.6b

[17] Rose REC, Felix R, Crawford-Sykes A, et al: Extravasation Injuries. West Indian Med J. 2008; 57: 40-47. PMid:19565937

[18] Jordan K, Behlendorf T, Mueller F. Anthracycline extravasation injuries: management with dexrazoxane. Therapeut Clinic Risk Management. 2009; 5: 361-366. http://dx.doi.org/10.2147/TCRM.S3694

[19] Brothers TE, Von Moll LK, Niederhuber JE, et al. Experience with subcutaneous infusion ports in three hundred patients. Surg Gynecol Obstet. 1988; 166: 295-301. PMid:3127896

[20] Schulmeister L. Managing Vesicant Extravasations. Oncologist. 2008; 13: 284-288. PMid:18378538 http://dx.doi.org/10.1634/theoncologist.2007-0191

[21] Quintanar-Verdúguez T, Jarava AB, Blanca M, et al. Mediastinal extravasation of doxorubicin, Case Report. Clin Translat Oncol. 2008; 10: 128-130. http://dx.doi.org/10.1007/s12094-008-0167-z

[22] Barrios CH, Zuke JE, Blaes B, et al. Evaluation of an Implantable Venous Access System in a General Oncology Population. Oncology. 1992; 49: 474-478. PMid:1465287 http://dx.doi.org/10.1159/000227095

[23] Lokich JJ, Bothe A Jr, Benotti P, et al. Complications and management of implanted venous access catheters. J Clin Oncol. 1985; 3: 710-717. PMid:3923161

[24] Inan I, O Myers P, Braun R et al: Pyoderma gangrenosum after totally implanted central venous access device insertion (Case report). W J Surgic Oncol. 2008; 6: 31-36. PMid:18325095 http://dx.doi.org/10.1186/1477-7819-6-31

[25] Gallieni M, Pittiruti M, Biffi R, Vascular Access in Oncology Patients. CA Cancer J Clin. 2008; 58: 323-346. PMid:18971486 http://dx.doi.org/10.3322/CA.2008.0015

[26] Pingpank JF Jr.. Vascular Access and Specialized Techniques. In: DeVita VT Jr., Lawrence TS, Rosenberg SA (Eds.): Cancer, Principles \& Practice of Oncology, 9th Edition, Wolters Kluwer/Lippincott Williams \& Wilkins, Philadelphia, Baltimore, New York, London, Buenos Aires, Hong Kong, Sydney, Tokyo. 2011: 640-648

[27] Povoski SP. Long-term venous access. In: Pazdur R, Coia LR, Hoskins WJ, et al (Eds.): Cancer Management: A Multidisciplinary Approach (Medical, Surgical \& Radiation Oncology), CMP Healthcare Media, Washington. 2005: 935-947.

[28] Espinosa E, Pinto Á, Zamora P, et al. Palliative care is a key component of daily practice in oncology: descriptive study of hospitalisation events at an oncology treatment centre. Support Care Cancer. 2010; 18: 1231-1234. PMid:20508952 http://dx.doi.org/10.1007/s00520-010-0903-0

[29] Lewis J, Micklethwaite K, Stephens M, et al Administration and Safe Handling of Cytotoxic Drugs, Document No: SSW_PD2010_019, Publication (Issue) Date: June, 2010. Available from: http://www.sswahs.nsw.gov.au/pdf/policy/SSW_PD2010_019.pdf 
[30] Kaasa S, Loge JH. Quality-of-life assessment in palliative care. Lancet Oncol. 2002; 3: 175-182. http://dx.doi.org/10.1016/S1470-2045(02)00682-4

[31] Schaaefer KG, Selvaggi K, Abrahm JL. Specialized Care of the Terminal Ill, In: DeVita VT Jr., Lawrence TS, Rosenberg SA (Eds.): Cancer, Principles \& Practice of Oncology, 9th Edition, Wolters Kluwer/Lippincott Williams \& Wilkins, Philadelphia, Baltimore, New York, London, Buenos Aires, Hong Kong, Sydney, Tokyo. 2011: 2481-2491

[32] Ackermann M, Allen C, Armbruster W-J, et al. Extravasation Guidelines, COG Pharmacy Committee in Collaboration with COG Nursing Clinical Practice Committee: Acute/Palliative Care Section. Available from: http://www.phop.ch/docs/HOP/COG_extravasation_guidelines.pdf

[33] Pikó B, Puskásné Szatmári K, Bassam A, et al: Paravasation of cytostatic drugs, (abstract in English), Hungarian Oncol. 2011; 55: 4-13.

[34] Robinson-Bostom L, Kawaoka J, Rupani R. et al: Alopecia and Cutaneous Complications. In: Abeloff MD, Armitage, JO, Niederhuber JE, et al. (Eds.): Abeloff's Clinical Oncology. Churchill Livingstone Elsevier. Philadelphia, 2008. Available from: http://www.mdconsult.com/das/book/body/221743928-7/0/1709/46.html?tocnode=55015704\&fromURL=46.html\#4-u1.0-B9780-443-06694-8..50045-2_1190

[35] White S, Robinson J, Barr E, et al. Chemotherapy extravasation guideline - WOSCAN (West of Scotland Cancer Advisory Network) Cancer Nursing and Pharmacy Group), Date written: September 2009. Available from: http://www.beatson.scot.nhs.uk/content/mediaassets/doc/Extravasation\%20guidance.pdf

[36] Van Den Brande J, Vermorken JB. Practical implications of cytotoxic drug administration. CME Journal of Gynecologic Oncology 43-5. Available from: http://www.cme.hu/dlObject.php?aid=265\&/043-51brande.pdf

[37] Nogler-Semenitz E, Mader I, Fürst-Weger P, et al. Extravasation of cytotoxic agents (abstract in English). Wiener Klin Wschr. 2004; 116: 289-295. PMid:15237653 http://dx.doi.org/10.1007/BF03040898

[38] Heitmann C, Durmus C, Ingianni G. Surgical Management after Doxorubicin and Epirubicin Extravasation. J Hand Surgery. 1998; 23: 666-668. http://dx.doi.org/10.1016/S0266-7681(98)80024-7

[39] Heidary N, Naik H, Burgin S. Chemotherapeutic agents and the skin: An update. J Am Acad Dermatol. 2008 ; 58: 545-70. PMid:18342708 http://dx.doi.org/10.1016/j.jaad.2008.01.001

[40] Langer SW, Sehested M, Jensen PB. A Focus on the Treatment of Anthracycline Extravasation and Tissue Protection; Supportive Oncology. Available from: http://www.touchoncology.com/files/article_pdfs/Jensen.pdf

[41] Wengström Y, Foubert J, Margulies A, et al Introducing the Extravasation Guidelines 2007. Available from: http://www.cancernurse.eu/documents/EONSClinicalGuidelinesSection6-en.pdf

[42] Larson DL. Treatment of Tissue Extravasation by Antitumor Agents. Cancer. 1982; 49: 1796-1799. http://dx.doi.org/10.1002/1097-0142(19820501)49:9<1796::AID-CNCR2820490911>3.0.CO;2-M

[43] McDonald L. Knowledge is power when treating extravasation reactions. Posted December 1, 2001. HemOnctoday (Clinical News in Oncology and Hematology). Available from: http://www.hemonctoday.com/articlePrint.aspx?type=print\&rID=23825

[44] Rosenthal K: Infiltrations \& Extravasations. Available from: http://www.resourcenurse.com/feature_infiltration.html

[45] Rosenthal K: Reducing the risks of infiltration and extravasation - Protect your patients from potentially disabling complications by following these practice guidelines. Available from:

http://journals.lww.com/nursing/Fulltext/2007/11001/Reducing_the_risks_of_infiltration_and.1.aspx

[46] Bartal A, Mátrai Z, Rosta A, et al. Implementation of an extravasation protocol at the National Institut of Oncology. Hungarian Oncol. 2011; 55: 14-20.

[47] Lodriguss J. The Ethics of Digital Manipulation. Available from: http://www.astropix.com/HTML/J_DIGIT/ETHICS.HTM

[48] Mohan K. Photography Post Processing Workshop Using Adobe Lightroom. Available from: http://www.drkrishi.com/photography-post-processing-workshop-using-adobe-lightroom

[49] Without Author: Cambridge in colour - A Learning Community for Photographers. Available from: http://www.cambridgeincolour.com/

[50] Without Author: Photo Manipulation Policies. Available from: http://www.consumerwebwatch.org/pdfs/photos_policies.pdf

[51] Guyatt GH, Cook DJ, Jaeschke R, et al. Grades of Recommendation for Antithrombotic Agents - American College of Chest Physicians Evidence-Based Clinical Practice Guidelines (8th Edition). Chest 133:123-131, 2008

[52] Without Author: Paravasate of cytostatic drugs (ESMO Guidelines). Available from: http://www.esmo.org/career/practice-tools/non-interactive-practice-tools/paravasate- of-cytostatic-drugs.html

[53] Without Author: Quality Standard for the Oncology Pharmacy Service (QuapoS 4). Available from: http://www.esop.li/downloads/library/quapos4_engl_no_com.pdf

[54] Scuderi N, Onesti MG. Antitumor agents: extravasation, management, and surgical treatment. Ann Plast Surg. 1994 ; $32: 39-44$. PMid:8141535 http://dx.doi.org/10.1097/00000637-199401000-00008 
[55] Foo KF, Michael M, Toner1 G, et al. A case report of oxaliplatin extravasation. Ann Oncol. 2003; 14: 961-962. PMid:12796037 http://dx.doi.org/10.1093/annonc/mdg252

[56] European Medicines Agency. Savene Product information. Available from: http://www.emea.europa.eu/docs/en_GB/document_library/EPAR_-_Product_Information/human/000682/WC500049102.pdf

[57] Berghammer P, Pöhnl R, Baur M, et al. Docetaxel extravasation. Supp Care Cancer. 2001; 9: 131-134. PMid:11305072 http://dx.doi.org/10.1007/s005200000182

[58] Drugs, Detralex. Available from: http://www.drugs.com/international/detralex.html

[59] Gault DT. Extravasation Injuries. Br J Plat Surg. 1993; 46: 91-96. http://dx.doi.org/10.1016/0007-1226(93)90137-Z

[60] Khan MS, Holmes JD. Reducing the morbidity from extravasation injuries. Ann Plast Surg. 2002; 48: 628-632. PMid:12055433 http://dx.doi.org/10.1097/00000637-200206000-00011

[61] Steinmann G, Charpentier C, O’Neill TM, et al. Liposuction and extravasation injuries in ICU. Br. J. Anaesth. 2005; 95: 355-357. PMid:16024586 http://dx.doi.org/10.1093/bja/aei193

[62] Vandeweyer E, Heymans O, Deraemaecker R. Extravasation Injuries and Emergency Suction as Treatment. Plast Reconstr Surg. 2000; 105: 109-110. PMid:10626979 http://dx.doi.org/10.1097/00006534-200001000-00019

[63] Cohan RH, Ellis JH, Garner WL. Extravasation of Radiographic Contrast Material: Recognition, Prevention, and Treatment. Radiology. 1996; 200: 593-604. PMid:8756899

[64] Kumar RJ, Pegg SP, Kimble RM, Roy M, et al. Management of extravasation injuries. ANZ J Surgery. 2001; 71: $285-289$. PMid:11374477 http://dx.doi.org/10.1046/j.1440-1622.2001.02104.x

[65] BC Cancer Agency Cancer Drug Manual - Bevacizumab; Revised: 1 December 2007; 1 September 2009, 1 July 2010. Available from:

http://www.bccancer.bc.ca/NR/rdonlyres/52C02943-7379-4B24-BC9D-A20AF1A3A1D2/46033/bevacizumab_monograph_1Jul y2010_formatted.pdf

[66] BC Cancer Agency Cancer Drug Manual - Cetuximab; Revised: 1 February 2010. Available from: http://www.bccancer.bc.ca/NR/rdonlyres/34F55B3F-8EE6-4534-8F6B-AB9E5A83324E/44005/Cetuximabmonograph_01Feb20 10_formatted.pdf

[67] BC Cancer Agency Cancer Drug Manual - Panitumumab; Developed: 1 August 2009. Available from: http://www.bccancer.bc.ca/NR/rdonlyres/59C0F607-E021-4CB0-8187-791E3E9150E3/38150/Panitumumabmonograph_1Aug0 9.pdf 